\title{
Sustaining Rainwater Harvesting for Household Water Supply in Awka Urban Area, Nigeria
}

\author{
Ezenwaji E. E. ${ }^{1, *}$, Uwadiegwu B. O. $^{2}$, Anyaeze E. U. ${ }^{2}$ \\ ${ }^{1}$ Department of Geography and Meteorology, Nnamdi Azikiwe University, Awka \\ ${ }^{2}$ Department of Environmental Management, Nnamdi Azikiwe University, Awka \\ *Corresponding author: emmaezenwaji@gmail.com
}

\begin{abstract}
The perennial scarcity of water supply in Awka has been a concern to its inhabitants. This is because of the complete absence of urban water supply system for the town. Consequently, shallow wells, vending, as well as rainwater harvesting are the major sources of water supply. This study examines how rainwater harvesting can be sustained to ensure the steady water supply to households in Awka. Data were collected from questionnaire and NIMET, and were analysed through statistical methods. Result shows that rainwater potential in the town amounts to 24, 658,000 litres enough for the annual household water needs.
\end{abstract}

Keywords: data, households, perennial, rainwater and sustaining

Cite This Article: Ezenwaji E. E., Uwadiegwu B. O., and Anyaeze E. U., "Sustaining Rainwater Harvesting for Household Water Supply in Awka Urban Area, Nigeria.” American Journal of Water Resources, vol. 5, no. 3 (2017): 85-91. doi: 10.12691/ajwr-5-3-4.

\section{Introduction}

The perennial water supply problem in Awka urban area has been a source of worry to government, establishment and households. However, households seem to be worst hit as this is the sector where the consumption of poor quality water is not given much consideration. For households in Awka town, there are many sources of water supply that they depend on which are surface water bodies, shallow wells boreholes, water vendors and rainwater harvesting. Among all these sources, rainwater harvesting is regarded as the least patronized [1,2,3]. This is one of the reasons why research in rainwater harvesting in the town has been scarce. Apart from [3] no known attempt has been made to study the potential of rain water harvesting as an alternative source of water supply for households who lack access to pipe borne water supply systems in the town. However, not only is the potential of this source of water supply be studied but also how it could be sustained to continuously complement other sources of water supply especially shallow wells and vendors. In spite of the fact that shallow wells and water vendor sources are very much patronized the advantages of rainwater harvesting by far outweigh all of them. Such advantages include the large number of potential catchment surfaces available in the town where over 98\% of the houses are roofed with corrugated iron sheets, asbestos and tiles. Again, it does not require travelling any distance to collect and is not bought with money, harvesting rainwater from an impervious urban environment especially as such is found in Awka generates a lot of flood water wherever it rains and this destroys life and property. The generation of flood water means that soil water recharge is impaired while flooding and soil erosion manifest. However, rainwater has its problems, which include poor water quality especially during the onset of the rains when the roofs are covered with the dry season dust. Furthermore, is the poor construction techniques for its harvesting as well as the best way to finance its associated projects $[4,5,6,7]$.

However, the benefits of relying on this source of water supply by far outweigh the problems associated with it.

Although, researchers have outlined and discussed the benefits and problems of this source of water supply, the study of the best way to sustain this ready source of water supply in Awka has been very scanty. The aim of the study is, therefore, to examine how rainwater harvesting can be sustained to ensure the steady water supply to households in Awka. In addition what are the factors that will guarantee a sustainable rainwater harvesting and to what extent will the water planners be involved?

\section{Materials and Method}

\subsection{The Area of Study}

Awka, the Capital of Anambra State is located between Lat $6^{0} 11^{1} \mathrm{~N}$ and $6^{0} 15^{1} \mathrm{~N}$ and Longitude $7^{0} .04^{1} \mathrm{E}$ and $7^{0} .09^{1} \mathrm{E}$. The town is traversed by the Onitsha - Enugu dual carriage highway. It is bound in the north-west by Okpuno, north-east by Amansea, south-west by Amawbia and south-east by Nibo (Figure 1).

Awka shares a boundary to the north with Ugwuoba in Enugu State, while its built up area of the town is about $7 \mathrm{~km}$ stretch from Amawbia junction [8] (Anambra State 
Physical Planning Board, 2015). It has a low lying topography as it sits on the Mamu river plain with all parts not above 333m above sea level. The major topographical features of the town are two cuest as one in the east and the other in the west, and these two join together outside the town to form part of Awka - Orlu upland. Its climate is characterized by two clear season's namely; rainy and dry seasons. The rainy season lasts for 8 months while the dry season lasts for 4 months. The annual rainfall is about $1850 \mathrm{~mm}$ per annum while temperature averages about $28^{\circ} \mathrm{C}$ throughout the year.

The geological formation that underlies the town are Imo formation and Bende - Ameki with small localization of Ebenebe formation. Vegetation is the rainforest, but most of it has been cleared to leave patches of guinea savanna. It has the 2015 population of 383,104 which was calculated with 5\% growth rate from the 2006 census base year.

\subsection{Data Collection}

Primary data was collected by the use of questionnaire which was designed for the work while secondary data was collected from the Amawbia Synoptic Station from where the twelve months rainfall for 2014 was collected for analysis. Data were also collected from other related studies as well as fieldwork.

The simple random sampling method was employed in the administration of the questionnaire to households. The definition of households followed that of [9] which is a married person with a family or an unmarried person of at least 20 years living alone and earning income. The UN approved average household size for Awka is 6 and this implies that Awka has 62,342 households if we divide the population by the household size of 6 . The monthly rainfall for Awka in 2014 as well as the mean, SE mean and standard deviation are presented in Table 1.

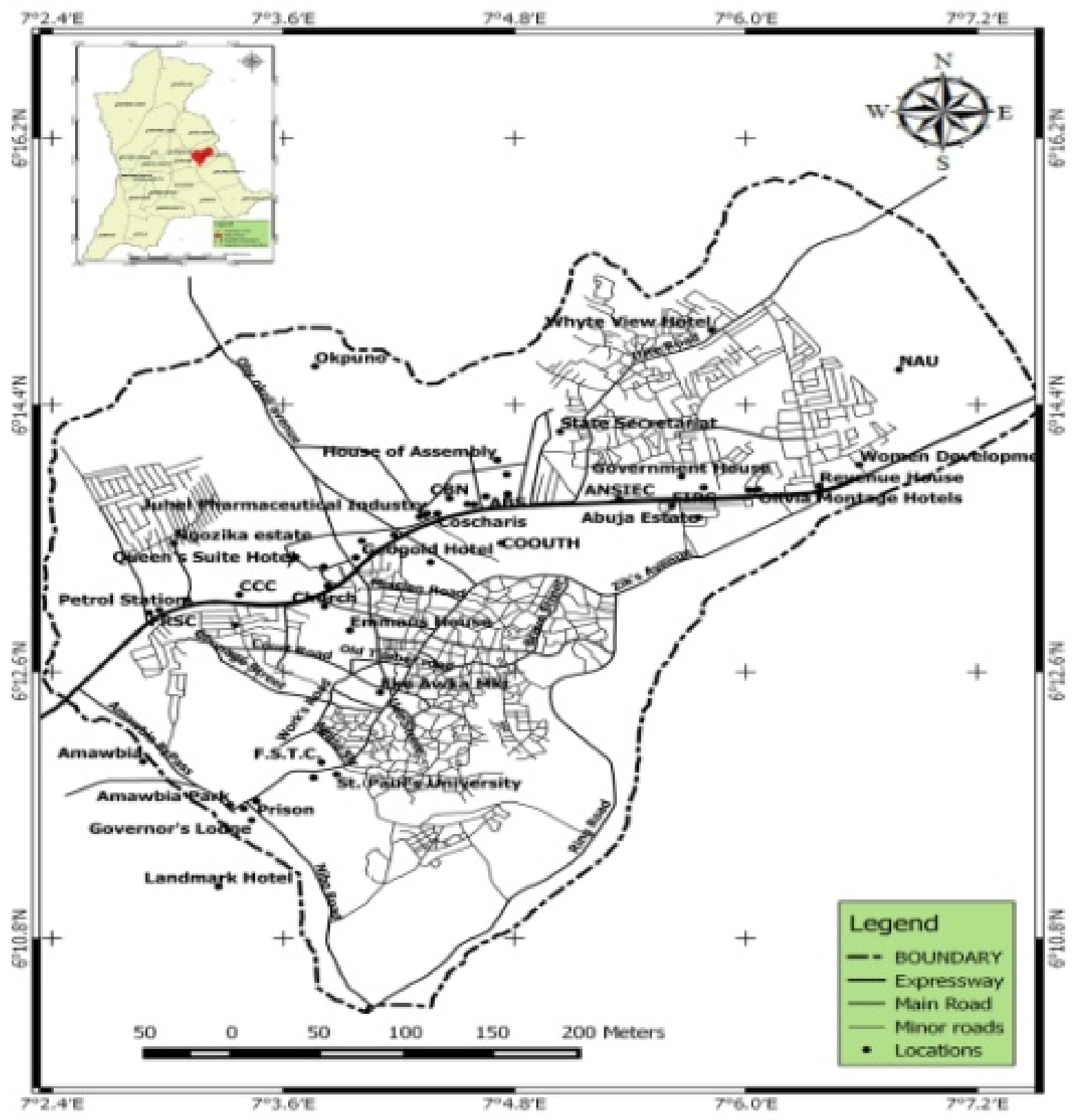

Figure 1. Map of the Study Area 
Table 1. Descriptive Statistics of Rainfall in Awka

\begin{tabular}{|c|c|c|c|c|c|}
\hline S/No. & Month & $\begin{array}{c}\text { Rainfall Total } \\
(\mathrm{mm})\end{array}$ & $\begin{array}{l}\text { Mean } \\
(\mathrm{mm})\end{array}$ & $\begin{array}{c}\text { SE Mean } \\
(\mathrm{mm})\end{array}$ & $\begin{array}{c}\text { St. Deviation } \\
(\mathrm{mm})\end{array}$ \\
\hline 1. & January & 81.4 & 2.62 & 1.42 & 7.89 \\
\hline 2. & February & 3.6 & 0.12 & 0.089 & 0.48 \\
\hline 3. & March & 127.2 & 4.10 & 1.67 & 9.31 \\
\hline 4. & April & 150.2 & 5.00 & 1.5 & 8.24 \\
\hline 5. & May & 187.5 & 6.05 & 1.91 & 10.62 \\
\hline 6. & June & 180.3 & 6.01 & 1.07 & 5.87 \\
\hline 7. & July & 300.4 & 9.69 & 2.93 & 16.29 \\
\hline 8. & August & 193.7 & 6.24 & 1.77 & 9.84 \\
\hline 9. & September & 359.7 & 12.00 & 2.9 & 15.91 \\
\hline 10. & October & 162.6 & 5.20 & 1.69 & 9.41 \\
\hline 11. & November & 93.5 & 5.43 & 3.26 & 17.85 \\
\hline 12. & December & 29.9 & 0.96 & 0.96 & 34.13 \\
\hline
\end{tabular}

The Table above shows average volume of rainfall in the location with respect to each month. The standard error can be used to construct intervals which is presented in Table 2. The interval comprises lower and upper boundaries. The lower boundary is the difference between the mean value and standard error of the mean. The upper boundary is the addition of mean value and the standard error.

Table 2. The Monthly Interval of Mean Values

\begin{tabular}{|c|c|c|}
\hline Min & Observed & Max \\
\hline 0.63 & 2.62 & 3.47 \\
\hline 0 & 0.12 & 0.18 \\
\hline 1.79 & 4.10 & 5.13 \\
\hline 2.84 & 5.00 & 5.84 \\
\hline 4.14 & 6.05 & 7.96 \\
\hline 3.61 & 6.01 & 5.75 \\
\hline 6.44 & 9.69 & 12.3 \\
\hline 3.82 & 6.24 & 7.36 \\
\hline 8.09 & 12.00 & 13.89 \\
\hline 2.91 & 5.20 & 6.29 \\
\hline 2.17 & 5.43 & 8.69 \\
\hline 1.0 & 0.96 & 12.6 \\
\hline
\end{tabular}

\section{Results and Discussion}

\subsection{Results}

The values in Table 2 are represented in the line graph (Figure 2).

Figure 2 shows that there is every indication that the town will experience extremes high and low rainfall in the nearest future. This shows that rainwater as a source of water supply may be greatly affected in future by climate change and hence the need to study it now.

The total water supplied from rainfall for Awka can be estimated using the equation

$$
\mathrm{S}=\mathrm{R} \times \mathrm{A} \times \mathrm{Cr}
$$

Where

$\mathrm{S}=$ mean rainwater supply in $\mathrm{m}^{3}$

$\mathrm{R}=$ mean annual rainfall in $\mathrm{mm} /$ per annum

$\mathrm{A}=$ catchment area in $\mathrm{m}^{2}$ (This is the total area of roofs in the Town)

$\mathrm{Cr}=$ runoff coefficient.

The necessary factors that will sustain rainwater harvesting were collected from the 33 wards of Awka as follows. However, Table 3 shows the labeling and interpretation of the factors.

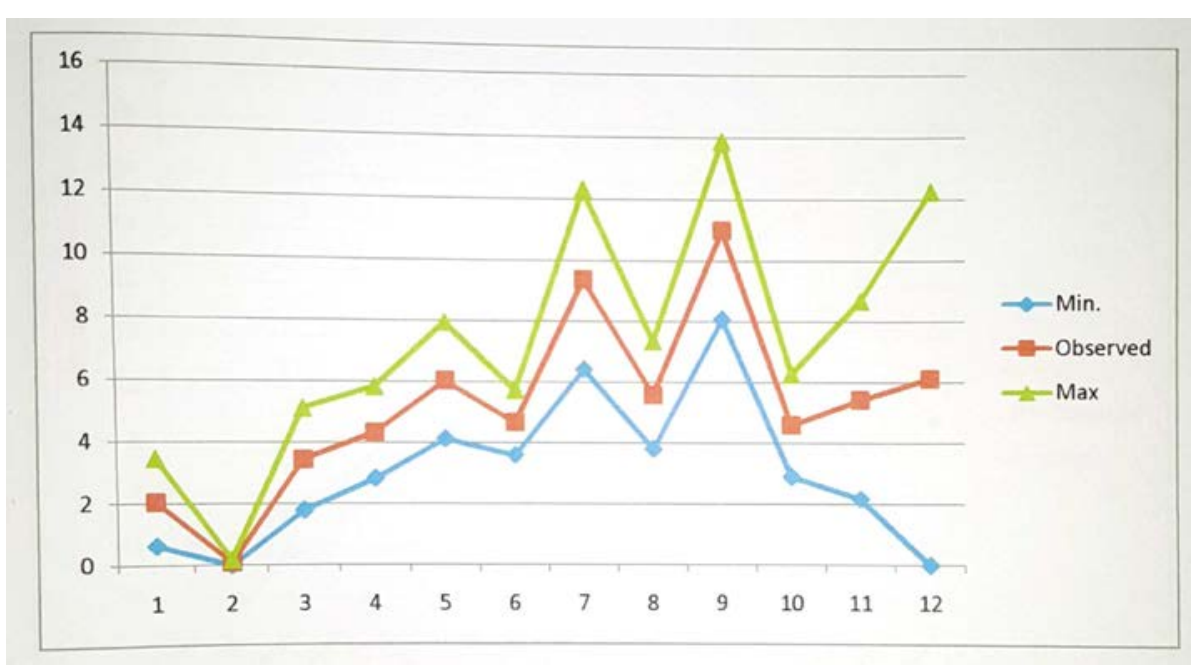

Figure 2. Line Chart of Average Monthly Rainfall with Minimum and Maximum Value 
Table 3. Sustainability Factors of Rainwater Harvesting in Awka

\begin{tabular}{|c|c|c|l|}
\hline S/N & Variable Label & Variable Code & Variable Interpretation \\
\hline 1. & HON & $\mathrm{X}_{1}$ & Number of houses with zinc roofs with tiles \\
\hline 2. & COL & $\mathrm{X}_{2}$ & Number of houses with gutters round the roof and down pipes \\
\hline 3. & HOW & $\mathrm{X}_{3}$ & Whether or not State water policy included rainwater Harvesting \\
\hline 4. & DAI & $\mathrm{X}_{4}$ & Household daily water consumption \\
\hline 5. & SIZ & $\mathrm{X}_{5}$ & Size of water storage tanks in the household \\
\hline 6. & RAI & $\mathrm{X}_{6}$ & Amount of rainwater supply in litres per annum in the town \\
\hline
\end{tabular}

The above variables recorded the highest frequencies from respondents among many factors presented to them that will aid sustainability of rainwater harvesting in the urban area. The variables were defined and parametized for analysis and Table 4 shows a record of the field data from the 33 wards that make up the town.

Table 4. Factors of Rainwater Sustainability in Awka

\begin{tabular}{|c|l|c|c|c|c|c|c|}
\hline \multirow{2}{*}{ S/N } & \multirow{2}{*}{ Wards } & \multicolumn{5}{|c|}{ Variables } \\
\cline { 2 - 7 } & & $\mathbf{X}_{\mathbf{1}}$ & $\mathbf{X}_{\mathbf{2}}$ & $\mathbf{X}_{\mathbf{3}}$ & $\mathbf{X}_{\mathbf{4}}$ & $\mathbf{X}_{\mathbf{5}}$ & $\mathbf{X}_{\mathbf{6}}$ (litres) \\
\hline 1. & Achallaoji & 2 & 1 & 1 & 610 & 1 & 610,880 \\
\hline 2. & Agbana & 2 & 1 & 1 & 600 & 3 & $1,720,900$ \\
\hline 3. & Agbana-Ifite & 1 & 3 & 4 & 620 & 3 & $1,820,171$ \\
\hline 4. & Amachalla & 1 & 2 & 1 & 630 & 4 & 765,840 \\
\hline 5. & Amudo & 2 & 2 & 1 & 690 & 3 & 780,673 \\
\hline 6. & Igweogige & 1 & 4 & 1 & 600 & 2 & 690,000 \\
\hline 7. & Isiagu & 1 & 1 & 4 & 600 & 2 & 880,650 \\
\hline 8. & Obunagu & 1 & 4 & 5 & 620 & 2 & $1,694,760$ \\
\hline 9. & Okperi & 1 & 3 & 5 & 590 & 1 & 860,000 \\
\hline 10 & Omuko & 1 & 1 & 4 & 640 & 3 & 941,080 \\
\hline 11 & Enu-Ifite & 1 & 2 & 4 & 600 & 3 & 574,065 \\
\hline 12 & Ezinato-Ifite & 2 & 3 & 4 & 600 & 3 & 717,230 \\
\hline 13 & Umuayom & 1 & 1 & 4 & 620 & 3 & 732,727 \\
\hline 14 & Umuenechi & 2 & 1 & 3 & 600 & 3 & 693,640 \\
\hline 15 & Umubele & 1 & 2 & 1 & 610 & 4 & 1504,989 \\
\hline 16. & Umunnoke & 1 & 1 & 1 & 610 & 3 & 460,160 \\
\hline 17. & Umuoramma & 1 & 2 & 5 & 590 & 3 & 256,280 \\
\hline 18. & Umuokpu & 1 & 1 & 4 & 600 & 1 & 350,375 \\
\hline 19. & Umunamoke & 2 & 3 & 3 & 590 & 4 & 390,268 \\
\hline 20. & Umudiaba & 1 & 1 & 4 & 600 & 4 & $1,394,800$ \\
\hline 21. & Umuzocha & 1 & 1 & 5 & 670 & 2 & 567,989 \\
\hline 22. & Umudiana & 2 & 1 & 3 & 630 & 3 & 716,710 \\
\hline 23. & Umueri & 1 & 2 & 5 & 610 & 2 & 385,742 \\
\hline 24. & Umuogwali & 1 & 1 & 4 & 610 & 3 & 575,330 \\
\hline 25 & Umuogbunu I & 1 & 1 & 3 & 650 & 3 & 300,240 \\
\hline 26. & Umuogbunu II & 1 & 1 & 2 & 640 & 3 & 557,310 \\
\hline 27. & Umudioka & 1 & 2 & 1 & 600 & 2 & 503,600 \\
\hline 28. & Umukwa & 1 & 1 & 3 & 600 & 1 & 458,550 \\
\hline 29. & Umuogbu & 2 & 1 & 1 & 600 & 3 & 550,280 \\
\hline 30. & Umuoruka & 1 & 1 & 1 & 560 & 3 & 630,820 \\
\hline 31. & Umuanaga & 1 & 1 & 2 & 640 & 3 & 429,560 \\
\hline 32. & Umuike & 2 & 3 & 600 & 3 & 667,330 \\
\hline Total & & & & & & $24,658,000$ \\
\hline
\end{tabular}

As already indicated, the values in Table 4 were arrived through the gathering of the relevant data from each of the above 33 wards. Moreover, all the new estates and layouts in the town are subsumed under any of the traditional wards.

The size of the supply of rainwater depends on the amount of rainfall, the area catchment, and its runoff coefficient [10]. For Awka town we have the relevant data for the calculation of mean rainwater supply in cubic meters, which was parametized in cubic meters and resolved into litres. With a total rainfall of about $1850 \mathrm{~mm}$ the mean was $154 \mathrm{~mm}$ in 2004 , the runoff coefficient was taken as 0.8 and the total surface area of the town was calculated to be $200,150 \mathrm{~m}^{2}$ then the mean rainwater is finally arrived at with the application of equation 1 .

$$
\begin{gathered}
\mathrm{S}=\mathrm{R} \times \mathrm{A} \times \mathrm{Cr} \\
\mathrm{S}=154 \mathrm{~mm} / \mathrm{a} \times 200,150 \mathrm{~m}^{2} \times 0.8 \\
=.154 \mathrm{~m} / \mathrm{a} \times 200,150 \mathrm{~m}^{2} \times 0.8 \\
=24,658 \mathrm{~m}^{3 / \mathrm{a}}=24,658,000 \mathrm{litres} / \text { annum } \\
=\frac{24,658,000}{365}=67,556 \text { litres per day. }
\end{gathered}
$$

However, in the field we were informed that average water use per household was 100 litres with each family having a mean of 6 members. The quantity of water required annually by each household was then calculated as 100 litres $\times 6 \times 365=219,000$ litres, and for all the 62,342 households, we have (219,000 litres x 62,342 households) 13,652,898 which is 37,405 litres per day. This means that the rainfall source had an excess of 30,158 litres i.e. 67,556 litres - 37,405 litres. This excess which is approximately 30 cubic meters were wasted as flood during the year which might have caused soil erosion and polluted surface water bodies.

Six variables isolated for study were employed in the calculation of multiple regression analysis with the amount of rainwater (Y) as dependent variable while others variables $\left(\mathrm{X}_{1}, \mathrm{X}_{2}, \mathrm{X}_{3}, \mathrm{X}_{4}\right.$ and $\left.\mathrm{X}_{5}\right)$ were independent variables. To ascertain the contributions of the variables to rainwater sustainability, the percentage variation explained by these independent variables to rainwater amount was arrived at with the equation below

$$
\begin{aligned}
X_{6}(Y)= & 221726+199580 x_{1}+147027 x_{2} \\
& +69245 x_{3}+1828 x_{4}+83123 x_{5} .
\end{aligned}
$$

To determine the variable which ranks highest in importance in sustaining rain water harvesting in the town, we assessed the weight of coefficient in each variable and further calculated its $p$-value and comparing the value 
with the model p-value of 0.05 to know those variables that are significant. As a decision rule, any parameter whose $p$-value is greater than the threshold of 0.05 is not significant (Table 5).

Table 5. Regression Model Result for each Parameter

\begin{tabular}{|c|c|c|c|c|}
\hline Predictor & Coefficient & SE Coefficient & T & P \\
\hline Constant & 221,726 & $1,357,441$ & 0.16 & 0.071 \\
\hline $\mathrm{X}_{1}$ & 199,580 & 164,481 & 1.21 & 0.035 \\
\hline $\mathrm{X}_{2}$ & 147,027 & 155,869 & -0.94 & 0.034 \\
\hline $\mathrm{X}_{3}$ & 69,245 & 39,180 & 1.77 & 0.018 \\
\hline $\mathrm{X}_{4}$ & 1828 & 2209 & 0.88 & 0.015 \\
\hline $\mathrm{X}_{5}$ & 83,123 & 69,430 & 0.20 & 0.242 \\
\hline
\end{tabular}

$\mathrm{R}-\mathrm{Sq}=76.7 \%$.

In Table 5 the large value of SE Coefficient for the base constant indicates that it is not significant because its SE coefficient is employed as an indication of the accuracy of the predictor. In this wise variable $\mathrm{X}_{4}$ has the lowest $\mathrm{SE}$ coefficient showing that it has the most accurate prediction in the model. Other parameters are however, significant with relative degrees as indicated with their SE coefficient and p-values. For the determination of the most significant parameter, the variable with the lowest p-value is $\mathrm{X}_{4}$ (Household daily water consumption) followed by $\mathrm{X}_{3}$ (whether or not the State water policy document included rainwater harvesting) and they are followed by $\mathrm{X}_{2}$ and $\mathrm{X}_{1}$ while $\mathrm{X}_{5}$ is not significant, means that $\mathrm{X}_{5}$ is not necessary in the model. To determine the size of water storage tanks, adequacy of the entire model, we used p-value less than 0.05 as was done earlier. This is calculated using the analysis of variance (Table 6).

Table 6. Analysis of Variance for the Regression Model

\begin{tabular}{|l|c|c|c|c|c|}
\hline Source & Df & Ss & Ms & F & P \\
\hline Regression & 5 & $6.01003 \mathrm{E}+11$ & $1.20201 \mathrm{E}+11$ & 11.08 & 0.033 \\
\hline Residual Error & 27 & $3.00133 \mathrm{E}+8$ & $1.11160 \mathrm{E}+6$ & & \\
\hline Total & $\mathbf{3 2}$ & $\mathbf{3 . 6 0 2 3 3 E}+\mathbf{1 9}$ & & & \\
\hline
\end{tabular}

From Table 6 we saw that p-value is less than 0.05 which implies that the model is rich enough to adequately explain variations in the dependent variable.

To show the wards with the highest contribution of the sustainability factor to rainwater amounts, cluster analysis was carried out which produced a dendogram (Figure 3 ).

In the dendogram ward 16 is shown as the ward that exhibits the highest potential of sustainable rainwater harvesting. It is followed by wards 23, 10 and 31 which belong to one group; all others belong to a separate group except wards 24 and 29 which are least engaged in the sustainable rainwater harvesting (Table 7).

Table 7. Categorization of Wards of Awka in terms of their engagement to sustainable rainwater harvesting

\begin{tabular}{|c|c|c|}
\hline Group & Wards & Performance \\
\hline 1 & 16 & Very high \\
\hline 2 & 23,10 and 31 & High \\
\hline 3 & $\begin{array}{c}1,2,3,4,5,6,7,8,9,11,12,13,14,15, \\
17,18,19,20,21,22,23,25,26,27,28\end{array}$ & Low \\
\hline 4. & 24,29 & Very low \\
\hline
\end{tabular}

\section{Dendrogram}

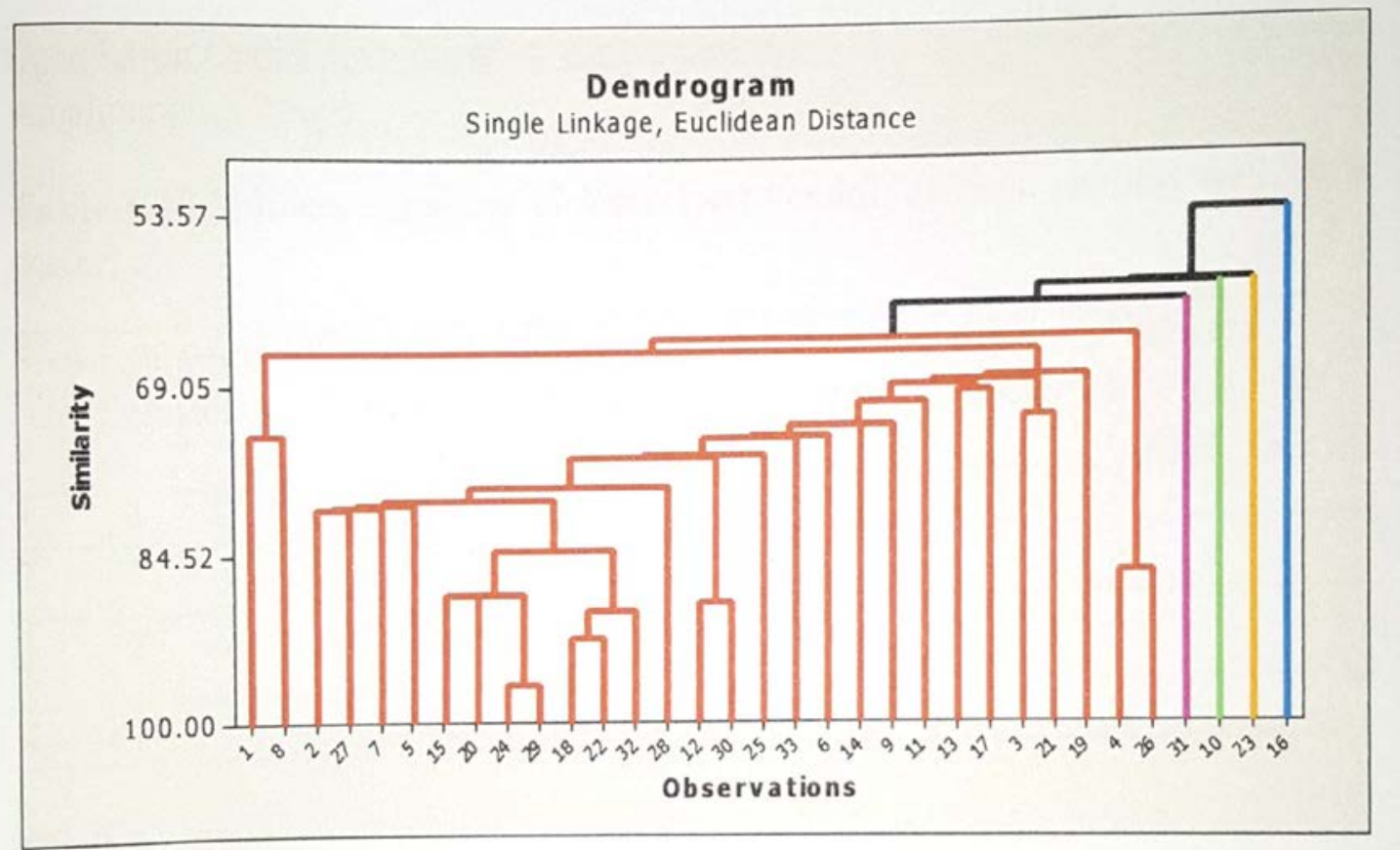

Figure 3. Dendogram Showing the Cluster of 33 Wards in the Town 


\subsection{Discussion}

It could be seen that the total rainwater supply in the town for 2014 was calculated to be 24,658,000 litres per annum while the total household water demand was $13,652,898$ litres per annum showing that the water supply from rainfall gives us excess of 30,398 litres after demand has been met. What this means in essence is that this excess was wasted and not only was that the case, the wastage supposedly caused some environmental problems like soil erosion and flooding. It is, therefore, necessary to educate households to increase their rainwater storage capacity and to ensure that they use gutter round the roof to gather all available rain water in the roof. The Ministry of Public Utilities and Water Resources should be able to determine the required storage capacity required for maximum use of rainwater harvesting in each household. As a result of the fact that proper storage capacity was not used, the model output show that the variable was not significant $\left(\mathrm{X}_{5}\right)$ The installed storage capacity should be examined by each household to ascertain whether in the event of the outpouring of rains the container can contain the entire rain water from the roof top. The relatively small tanks can only accommodate as much as their capacity can allow, while excess rainfall will as a matter of necessity be discarded as flood water. This is exactly the findings of [11] and [6] who found that an excess volume of rainwater is wasted when undersized storage capacity tanks are installed in the household.

Furthermore, [7] in his study of water storage capacity for single family households in Accra found that the installed capacity does not have a significant linear relationship with the roof area. This is one area where rainwater sustainability could be achieved because by installing large storage, households in the town can rely completely on rainwater throughout the year without supplementing from other sources.

The six variables of rainwater harvesting sustainability reveal that variable $\mathrm{X}_{4}$ (Household daily consumption of water) is the most important that could achieve rainwater sustainability in Awka town. The importance of this factor cannot be over emphasized since the consumption level of households in the town will to a large extent determine the overall water consumption when they are aggregated and summed. From Table 5 it could be seen that with a small coefficient of 1828 and a p-value of 0.015 , the variable could even be used to determine other factors in the sustainability of rainwater harvesting in the town. In this wise, the relevant authority needs to commission a more detailed study using this as a baseline. All over the world, levels of domestic water consumption varies with the family size and use pattern. This requires that household roof should be properly designed to meet essential household uses so that excess could not cause any environmental problem.

The next variable in importance as determined by the regression model is $\mathrm{X}_{3}$ (whether or not the State water policy includes rainwater harvesting). It is indeed very regrettable that this essential water supply sources to the households are not included in the policy document. In another study, [12] decried that the Anambra State Water Policy do not contain the sources of water supply that are traditional to the people despite the request for stakeholder during the public hearing before the passage of the policy into law. One of such traditional sources is the rainwater harvesting which is available to consumers every rainy season. Our view is that the relevant water authority in the State should convoke a stakeholders' meeting in which the bulk of participants are expected to come from the households who will be expected to share their experiences and concern. [13] noted that the basis of planning of any meaningful water project is the household and regretted the top bottom decision of the policy makers who usually decide and execute water projects without the input of core users. A related view was shared by [14] when he noted that any water policy that does not hand over ownership of such project to water uses is bound to be unsustainable. We cannot agree less with these authors, because despite the cries from water users in Anambra State, the policy document has remained outdated and irrelevant to the need of water users. There is now a call for the document to be revised to accommodate these identified critical areas.

Other factors are relatively stable in the model and therefore contribute in varying degrees to the sustainability of rainwater harvesting in the town. Such variables include $\mathrm{X}_{1}$ (number of houses with zinc roof) (0.35).This is important as not all roof types are good enough to release quality rainwater e.g. asbestos roof which will result in unsustainability. Again we have $\mathrm{X}_{2}$ (number houses with gutters around the roof and down pipes). This will necessarily ensure that all rainwater that falls on the roof are harvested. Then $\mathrm{X}_{5}$ (size of water storage tanks in households) is not significant because the installed storage capacity at the household was ignored and some instances completely without regard to the volume of rainwater that will be produced by the roof. This is one area that needs proper education of the households.

Finally we were able to determine the wards with the highest sustainability factors. In this wise, ward 16 which is Umunoke ward ranks the highest. During fieldwork, we found that most roofs in the ward were mainly white coloured and corrugated iron sheets that were fitted with gutters round the roof and accompanying down pipes that are channeled to the storage tanks. Some of the storage tanks are large underground tanks. The State government can use this ward to demonstrate the proper way to harness rainwater for household water supply.

\section{Conclusion}

The findings of this paper have highlighted the little knowledge which existed but have been ignored about rainwater harvesting in Awka town. The worry is that the government is yet to pay any attention to this cheap and available source of household water supply and this gives rise to waste and consequent environmental degradation, thereby indicating that it is not presently handled sustainably. The magnitude of the problems suggests a paradigm shift in strategy especially at this time when the State government cannot supply piped water to the people. The starting point in solving the problem is to encourage a partnership between the government and households in the management of rainwater harvesting. The bases of this 
partnership are two keyareas; household water consumption which could be sourced wholly from rainwater harvesting and an inclusive water policy that will promote this important traditional sources, as well as, an enabling social and economic environment that will ensure its sustainability.

\section{References}

[1] Otti V. I. and Ezenwaji E. E. (2013). Enhancing Community Driven Initiative in Rainwater Harvesting in Nigeria, International Journal of Engineering and Technology, 3(1), pp 73-79.

[2] Udebi C. O. (2014). Water Supply in some Wards of Awka Town: Journal of Community Water Resources, 1(1), pp 60-71.

[3] Okafor C. L. (2015). The Contributions of Rainwater Harvesting to Households Water Supply in Awka Town, Nigeria. Unpublished B.ScThesis, Nnamdi Azikiwe University, Awka.

[4] Bang Y, Brown D and Onwubiko A. (1981) Prevalence of Larvae of Potential Yellow Fever in Domestic Water Containers in S.E Nigeria. Bulletin of World Health Organization, 59(1), pp 107-114.

[5] Anyaegbu T. (2015). Financing Water Projects in Nigeria. Water Supply, 8(2), pp 602-611.

[6] Ezenwaji E. E, Nzoiwu C. P and Eduputa B. (2015). Enhancing
Urban Water Supply through Rainwater collection in Enugu Town. Atmospheric and Climate Sciences, 2(4), pp 16-29.

[7] Donkar E. A. (2016b). Statistical Analysis of Water Storage Capacity and daysof storage for Single - family Households in Accra. $39^{\text {th }}$ WEDC International Conference, Kumasi Ghana. $11^{\text {th }}-15^{\text {th }}$ July.

[8] Anambra Physical Planning Board, (2015). Mimeographed.

[9] Darr, P, Feldman, S. and Kanem C. (1975). "Socio-Economic Factors Affecting Domestic Water Demand in Israel. Water Resources Research, 6(1), pp 805-809.

[10] Gould, J., \& Nissen-Petersen, E. (1999). Rainwater catchment systems for domestic supply. Intermediate Technology.

[11] Karim J, Vhadr C. and Colman B. (2015): Water Supply using Rainwater Harvesting. Journal of Tropical Water Supply, 3(6), pp 114-126.

[12] Ezenwaji E. E. (2016). Self - Supply as a Traditional Model for the Improvement of Water Supply in Onitsha, Nigeria. Paper delivered at the $39^{\text {th }}$ International WEDC Conference, Kumasi, Ghana. $11^{\text {th }}-15^{\text {th }}$ July.

[13] Keyama K, Minami I. (1995). Rainwater Utilization in Izumo Dome and some Reformations for Automatic Rainwater Catchment System. Proceedings of the $7^{\text {th }}$ Rainwater Catchment Systems Conference, Beijing, China Section, 10, pp 113-120.

[14] Waller, D. H. (1982). Rainwater as a Water Supply Source in Bermuda. Proceedings of the International Conference on Rainwater System, Hawaii, Honolulu, pp 184-93. 